\title{
CORRELATION OF NUTRITIONAL STATUS OF MOTHER AND THE BIRTH WEIGHT OF THE BABY
}

\section{AVINASH H SALUNKHE*, ASHA PRATINIDHI, KAKADE SV, JYOTI A SALUNKHE, VAISHALI R MOHITE, TRUPTI BHOSALE}

Department of Community Health Nursing , Krishna Institute of Nursing Sciences, Krishna Institute of Medical Sciences Deemed to be University, Karad, Maharashtra, India. Email: salunkheah@gmail.com

Received: 09 October 2017, Revised and Accepted: 21 April 2018

ABSTRACT

Objective: The objective of this study is to correlate mother's nutritional status during pregnancy and determine the birth weight of the baby.

Methods: A comparative, exploratory approach and prospective cohort study design was used to find out mothers' nutritional status during pregnancy influences the birth weight of babies. The data were collected using structured interview schedule and dietary history by 24 h recall method from a randomly selected sample of 380 eligible mothers delivered at Krishna Hospital, Karad.

Results: There was a significant correlation between birth weight and calorie intake (correlation coefficient [r] $=0.595 ; \mathrm{p}<0.001 ; \mathrm{Chi}-\mathrm{square}=201.3$; $\mathrm{p}<0.001$.) A higher proportion of low birth weight babies, i.e., 105 (32.2\%) were delivered by the mothers consuming < $70 \%$ of protein ([r] $=0.245$; $\mathrm{p}<0.001 ; \chi 2=24.033 ; \mathrm{p}<0.001])$. There was correlation between birth weight and calcium intake of mothers $([\mathrm{r}]=0.525 ; \mathrm{p}<0.001 ; \chi 2=10.12 ; \mathrm{p}<0.001]$ "birth" weight and iron intake of mothers ([r] $=0.250 ; \mathrm{p}<0.001 ; \chi 2=13.798 ; \mathrm{p}<0.001)$.

Conclusion: The intake of calorie, protein, calcium, and iron of mother can significantly influence the weight of the newborn baby. Among all anthropometric parameters of the mother, weight gain was the strongest predictor of adequacy of the birth weight.

Keywords: Low birth weight, Nutritional status, Protein, Calcium, Iron, Pregnancy.

(C) 2018 The Authors. Published by Innovare Academic Sciences Pvt Ltd. This is an open access article under the CC BY license (http://creativecommons. org/licenses/by/4. 0/) DOI: http://dx.doi.org/10.22159/ajpcr.2018.v11i8.22992

\section{INTRODUCTION}

India alone accounts for $40 \%$ of low birth weight (LBW) babies born in the developing world [1,2]. LBW is, in turn, an immediate major determinant of malnutrition during infancy and childhood $[3,4]$. LBW is a significant public health problem as it has serious health, social, and economic consequences for the individual, family, and society at large. Inadequate intrauterine nutrition is the major cause of LBW in the developing countries $[5,6]$.

Nutritional status of mothers both before and during pregnancy is critical in determining the birth weight. There is also evidence that girls with LBW are likely to give birth to LBW babies as they grow into adults [7].

The studies conducted by Raman et al. [8], Kulkarni et al. [9], and Naidu and Rao [10] have found that there is a very strong connection between maternal nutrition, in particular, body mass index (BMI) and the birth weight of their children. Another study conducted by Dharmalingam et al. [11] provides a national focus and examines the relationship between a selected number of proximate factors and LBW among Indian children. They have investigated the role of mothers' nutritional status measured by their BMI in determining the birth weight of their most recent births. They have also explored the variation in the effect of maternal nutritional status on birth weight among the various states in India.

LBW infants $(<2500 \mathrm{~g})$ are at risk of morbidity and mortality at birth and during early days of life. Infant weight is directly linked to the status of maternal nutrition. Lower calorie and protein intake by a mother throughout the pregnancy can result in small size of the baby [12]. Assessment of the dietary intake of pregnant women is time-consuming and tedious process, hence there is scarcity of studies related to the actual food intake and birth weight of the baby. The dietary pattern of pregnant women varies from state to state and also in urban and rural population and subpockets within the states. There are very few studies undertaken on rural population of Western Maharashtra. Therefore, the present study was undertaken in Krishna hospital, Karad, to investigate mothers' selected parameters of nutritional status during pregnancy determining the birth weight of babies.

In this study, known things were the maternal factors affecting birth weight of the baby. They were studied by many researchers from India and other countries in different setting with different approaches. The important aspect we studied was correlation of calorie, protein, calcium, and iron intake of individual mother was calculated according to the Recommended Daily Allowance (RDA) and correlated with birth weight of the baby.

India and other countries, very few studies have focused on birth weight and their correlation with calorie, protein, calcium and iron intake of mothers during pregnancy. Therefore the investigator planned to conduct present on this aspect.

\section{METHODS}

A comparative, exploratory approach and a prospective cohort study design was used to identify maternal nutrition influencing the birth weight of the babies. The data were collected from a randomly selected apparently healthy 380 eligible pregnant women who were registered at antenatal clinic and planned to deliver at Krishna Hospital, Karad. The data were collected using structured interview schedule. Assessment of mothers was done by taking selected anthropometric maternal measurements such as height in $\mathrm{cm}$, weight in " $\mathrm{kg}$ " at registration, weight gain of the pregnant woman from registration to delivery in $\mathrm{kg}$, BMI, dietary history by 24-h recall method, and laboratory parameter of blood hemoglobin. The ethical clearance was obtained from 
institutional ethics committee. The data were collected after formal permission from hospital authorities and after taking informed consent from each respondent.

\section{4-h dietary recall}

Each woman was asked about her dietary intake by recall method. The mother recalled what and how much food was consumed and when it was consumed. The mothers were asked to express the consumption of all food items in terms of exact katori/wati/glass size, chapati or bhakari size and number, and spoon size (large, medium, and small). This information was used to compute the daily intake of cooked foods by converting the household measures into grams or kilograms. The daily intake of calories (Kcal); proteins (g); calcium (mg); and iron (mg) was calculated using conversion table and compared with Recommended Dietary Allowance (RDA) [13] of the caloric requirement during pregnancy add "of each pregnant woman was found out on individualized recommendations as per the Indian Council of Medical Research (ICMR) guidelines [13]. The recommendations take into consideration are body weight, type of work, and sex. The table of values for every $5 \mathrm{~kg}$ weight from $40 \mathrm{~kg}$ to $70 \mathrm{~kg}$ for women [13]. From this table, the individualized caloric requirements were found out. The individualized protein requirements were found out using the formula of $1.04 \mathrm{~kg}$ of weight $[14,15]$ at the time of registration as a proxy for prepregnancy weight. Calcium and iron requirements were taken from the general recommendations $[14,15]$ of the ICMR.

\section{Sample size}

The sample size was calculated for the present study using the following formula,

$$
\mathrm{n}=\mathrm{Z}^{2} \frac{(1-\mathrm{p})}{\mathrm{E}^{2} \mathrm{p}}
$$

where $\mathrm{Z}=$ the standard normal variate at $5 \%$ significance level (value of $\mathrm{Z}$ is $1.96=2$ )

$\mathrm{p}=4 \%$ preterm deliveries; $\mathrm{E}=$ Relative precision $=50 \%$

$$
\begin{gathered}
\mathrm{n}=\mathrm{Z}^{2} \frac{(1-p)}{\mathrm{E}^{2} \mathrm{p}} \\
\mathrm{n}=\frac{(1.96)^{2}(1-0.04)}{(0.50)^{2} \times 4} \\
\mathrm{n}=\frac{3.69}{0.01}
\end{gathered}
$$

n=369 Rounded off to 380 .

$n=380=$ final sample for the study.

Data were analyzed by SPSS version 16 using descriptive and inferential statistics.

1. Descriptive statistics-frequency, percentage mean and standard deviation (SD) where ever applicable.

2. Inferential statistics- $\chi^{2}$ test was used to see an association with respect to maternal risk factors for qualitative data and analysis of variance (ANOVA), Bonferroni multiple comparison test, and unpaired t-test for quantitative data.

\section{RESULTS}

The mean birth weight was $2708.5 \mathrm{~g}$ with SD of $\pm 486.1 \mathrm{~g}$. There were $105(27.6 \%)$ out of 380 babies who were LBW. Among those, $22(5.8 \%)$ were between $1000 \mathrm{~g}$ and $<1500 \mathrm{~g}$, 83, i.e., $21.8 \%$ of LBW babies were in the birth weight group of $2000-<2500 \mathrm{~g}$ and $275(72.4 \%)$ babies were in normal birth weight (NBW) category (Table 1).

Out of 380 women, there were 259 (68.1\%) women who delivered NBW (not preterm) babies and 73 (19.2\%) women who delivered intrauterine growth retardation (IUGR) (LBW). There were 32 (8.5\%) preterm babies who were also LBW and $16(4.2 \%)$ preterm but had NBW (Table 2).

The recommended daily calorie intake calculated for individual mother by weight at registration and age of mother as compared to actual daily intake indicated that $33(8.7 \%)$ mothers consumed $<70 \%$ of kcal. The mean birth weight of the babies born to mothers who were taking $<70 \%$ kcal was lowest, i.e., $2121.4 \pm 340.9$ and the proportion of LBW was $93.9 \%$ as compared to those who were consuming higher proportion of calories. The birth weight increased and the proportion of LBW decreased with the increasing proportion of calorie intake. The higher proportion of LBW babies, i.e., $105(32.2 \%)$ were delivered by the mothers consuming $<70 \%$ of protein $\left(\chi^{2}=201.3 ; p<0.001\right)$. There was a highly significant correlation between birth weight and proportion of calorie intake of mothers as compared to their individualized RDA [13] ( $r$ ) $=0.595 ; \mathrm{p}<0.001$ with $95 \%$ confidence interval (CI) of 0.5263 to 0.6557 (Table 3).

Protein intake was calculated for individual mother by weight at registration

The $326(85.8 \%)$ mothers consumed $<70 \%$ of g protein. The mean birth weight of mothers who were taking $<70 \% \mathrm{~g}$ of protein was lowest, i.e., $2647.6 \pm 474.7$ as compared to those who were consuming higher proportion of protein intake. There was a statically significant association between proportion of protein intake (g) of individualized recommended daily allowance and proportion of LBWs $\left(\chi^{2}=24.033 ; \mathrm{p}<0.001\right)$. There was significant correlation between birth weight and proportion of protein intake of mothers $(r)=0.245$; $p<0.001$ with $95 \%$ CI of $0.4475-$ 0.5938 . The mean protein intake of these subset of 380 mothers was $70.7 \mathrm{~g}$ with SD of $15.9 \mathrm{~g}$ (Table 3).

\section{Calcium intake and birth weight}

Those mothers consuming less RDA of calcium gave birth to the babies weighing significantly lesser and proportion of LBW being significantly higher than the babies born to mothers consuming calcium equal to or above $1200 \mathrm{mg} /$ day (Unpaired $\mathrm{t}=4.914$; $\mathrm{p}<0.001$ ). There was a significant association between calcium intake and the proportion of LBW $\left(\chi^{2}=10.12 ; \mathrm{p}<0.001\right)$. There was significant correlation between birth weight and proportion of calcium intake of mothers $(r)=0.525 ; p<0.001$ with $95 \% \mathrm{CI}$ of $0.2611-0.4376$. The mean calcium intake of these 380 mothers was $785.1 \mathrm{mg}$ with SD of $278.6 \mathrm{mg}$ (Table 3).

\section{Iron intake and births weight}

The mean iron intake of these subset of 380 mothers was $24.7 \mathrm{mg}$ with $\mathrm{SD}$ of $6.5 \mathrm{mg}$. The mean iron intake of these subset of 380 mothers was $24.7 \mathrm{mg} \pm$ SD $6.5 \mathrm{mg}$. There were 347 (91.3\%) mothers whose iron intake was less than the RDA (As prescribed by the ICMR for Indian pregnant women). (Table 3). Gave birth to low birth weight babies and proportion of LBW babies were significantly higher than the babies born to mothers consuming iron $35 \mathrm{mg}$ or more per day (unpaired $\mathrm{t}=2.034 ; \mathrm{p}=0.043 ; \chi 2=13.798 ; \mathrm{p}<0.001)$. There was significant correlation between birth weight and proportion of iron intake of mothers ( $r)=0.250 ; p<0.001$ with $95 \%$ CI of $0.1532-0.3420$ (Table 3 ).

The mean weight of the pregnant women at registration was $46.7 \mathrm{~kg}$, with SD of $8.9 \mathrm{~kg}$ minimum being $31 \mathrm{~kg}$ and maximum of $74 \mathrm{~kg}$ (Table 4).

\section{Mothers weight at registration and birth weight}

There was no significant difference between weight at registration and birth weight (ANOVA $\mathrm{F}=1.077, \mathrm{p}=0.359$ ). There was apparently higher mean birth weight for the babies born to the mothers weighing in the weight range of $40-45 \mathrm{~kg}$ as compared to the babies born to mothers with 
weight range of $45 \mathrm{~kg}-<50 \mathrm{~kg}$. Weight of mother at registration was not associated with the rate of LBW babies. $\left(\chi^{2}=3.442 ; p=0.328\right)$ (Table 4 ).

\section{Height and birth weight}

The mean height of the delivering women was $154.4 \mathrm{~cm}$ with an SD of $6.2 \mathrm{~cm}$. Minimum height was $127.0 \mathrm{~cm}$ and maximum was $170.0 \mathrm{~cm}$. There was no significant association between the height of mother and mean birth weight of babies. (ANOVA $\mathrm{F}=0.668, \mathrm{p}=0.648$ ). There

Table 1: Distribution of birth weight

\begin{tabular}{ll}
\hline Birth weight in (g) & Frequency (\%) \\
\hline $1000-1499$ & $9(2.4)$ \\
$1500-1999$ & $13(3.4)$ \\
$2000-2499$ & $83(21.8)$ \\
Subtotal of LBW babies & $105(27.6)$ \\
$2500-2999$ & $171(45.0)$ \\
$3000+$ & $104(27.4)$ \\
Subtotal of NBW babies & $275(72.4)$ \\
\hline
\end{tabular}

n=380. LBW: Low birth weight, NBW: Normal birth weight was no significant difference in the rate of LBW among different height groups of mothers although an apparently higher rate of LBW of $36.4 \%$ was observed for height of mother of $\leq 145 \mathrm{~cm}\left(\chi^{2}=3.466 ; \mathrm{p}=0.629\right)$ (Table 4)

The minimum weight before delivery was $40 \mathrm{~kg}$ and maximum was $87 \mathrm{~kg}$. The mean weight before delivery was $58.2 \mathrm{~kg}$ with an SD of $9.0 \mathrm{~kg}$. The mean weight gain from registration to delivery was $11.5 \mathrm{~kg}$ with an SD of $2.6 \mathrm{~kg}$ and minimum weight gain was $4 \mathrm{~kg}$ the maximum gain in weight was $15.1 \mathrm{~kg}$.

There was a significant direct correlation between the weight gain of the mother and the birth weight of the baby. As the weight gain increased, the mean birth weight also increased. The proportion of LBW decreased with increase in weight gain for all groups except the weight gain group of $10 \mathrm{~kg}-<12.5 \mathrm{~kg}$. There was a marginal and insignificant $\left(\chi^{2}=0.003484 ; \mathrm{p}=0.9529\right)$ increase of LBW from $43.5 \%$ to $44 \%$ between $7.5 \mathrm{~kg}$ and $<10 \mathrm{~kg}$ group and $10 \mathrm{~kg}-<12.5 \mathrm{~kg}$ group $\left(\chi^{2}=64.971 ; \mathrm{p}<0.001 ;\right.$ ANOVA F=31.214, $\left.\mathrm{p}<0.001\right)$ (Table 4).

Table 2: Distribution of LBW, NBW, preterm births, and not preterm births

\begin{tabular}{llll}
\hline Not preterm & Not preterm & Preterm & Preterm \\
\hline$(\geq 37$ weeks) and & $([\geq 37$ weeks) [IUGR]) but & $(<37$ weeks $)$ and & $(<37$ weeks $)$ and \\
NBW babies & LBW babies & LBW babies & NBW \\
$(\geq 2500 \mathrm{~g})$ & $(<2500 \mathrm{~g})$ & $(<2500 \mathrm{~g})$ & $(\geq 2500 \mathrm{~g})$ \\
$259(68.1 \%)$ & $73(19.2 \%)$ & $32(8.5 \%)$ & $16(4.2 \%)$ \\
\hline
\end{tabular}

n=380, IUGR: Intrauterine growth retardation. LBW: Low birth weight, NBW: Normal birth weight

Table 3: Calorie and protein intake as proportion of the individualized RDA and mean birth weight and proportion of LBW

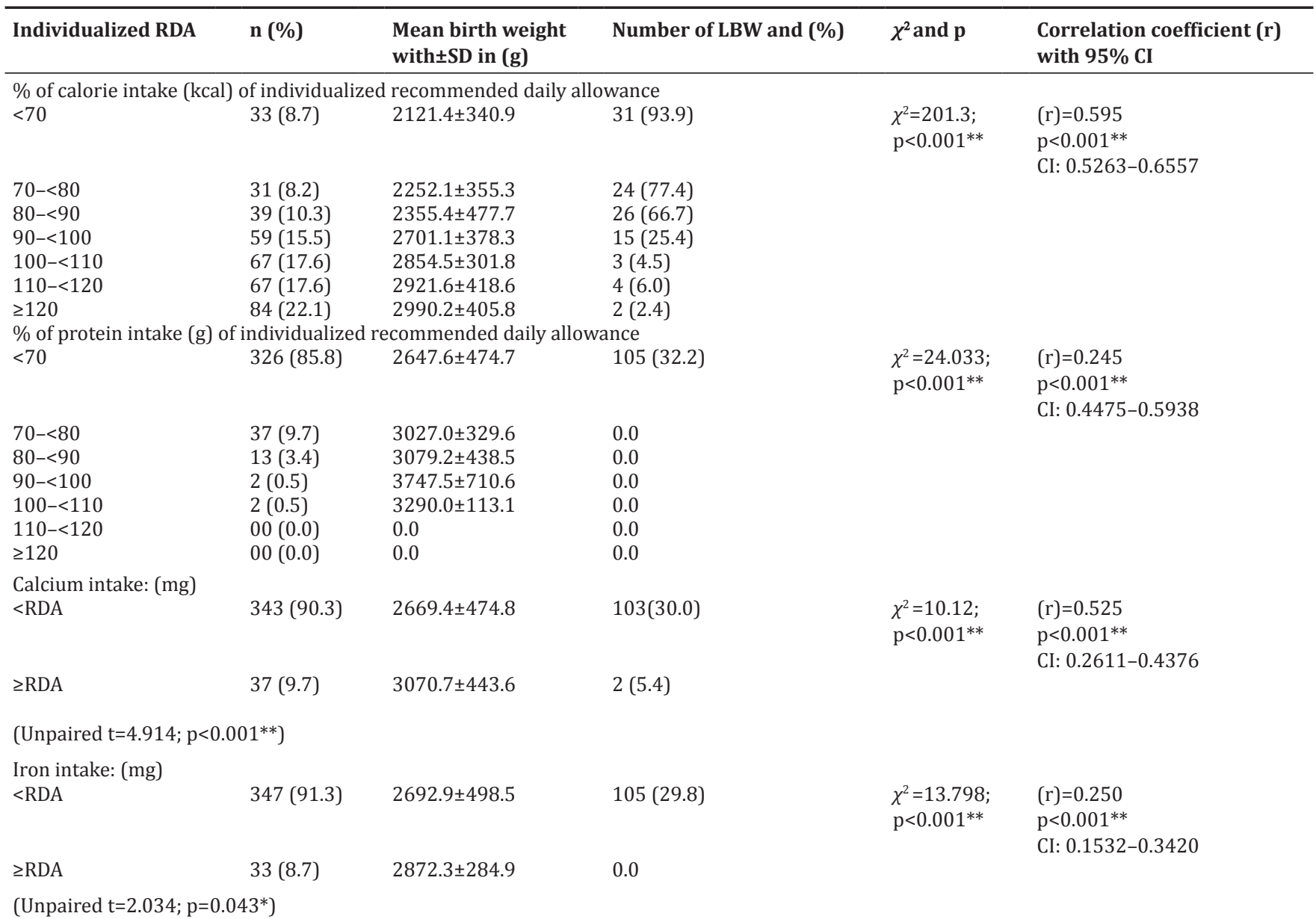

$\mathrm{n}=380$, RDA for sedentary type of work during pregnancy $\geq 2250 \mathrm{kcals}$, RDA for moderate type of work during pregnancy $\geq 2580$ kcals, RDA for heavy type of work during pregnancy $\geq 3200$ kcals Ref: $[14,15]$, significant $p<0.01^{* *}$ significant $\mathrm{p}<0.05^{*}$. LBW: Low birth weight, CI: Confidence interval, SD: Standard deviation 
Anemia at registration and birth weight

There was a significant difference between the basic hemoglobin level of the mothers at registration and the birth weight of the baby. (ANOVA $\mathrm{F}=4.111 ; \mathrm{p}=0.007^{* *}$ ). The Bonferroni multiple tests revealed that among all comparisons mild vs. moderate anemia was significant $(\mathrm{p}=0.013)$. The mean birth weight increased with increasing hemoglobin values. Those mothers with $<7 \mathrm{~g} \%$ hemoglobin in the first trimester were $3.7 \%$ who delivered babies with mean birth weight below $2500 \mathrm{~g}$ and proportion of LBW of (35.7). Anemia of all grades, i.e., mild, moderate, and severe was not associated significantly with higher rates of LBW $\left(\chi^{2}=3.767 ; \mathrm{p}=0.288\right)$. A very high proportion of pregnant women, i.e., $288(75.8 \%)$ was anemic. The proportion of LBW was 28.1 as compared to $26.1 \%$ in babies born to nonanemic mothers. This difference was not statistically significant. Mean birth weight of babies of anemic mothers was $2632.3 \pm 488.6 \mathrm{~g}$ and mean birth weight of babies of nonanemic mothers was $2715.4 \pm 462.8 \mathrm{~g}$. The babies born to nonanemic mothers weighed higher by $83.1 \mathrm{~g}$ (Table 5).

During the first trimester, there were 288 (75.8\%) women who were anemic and $43.2 \%$ could be classified as mild, $28.9 \%$, moderate, and $3.7 \%$ with severe anemia. The mothers showing mild or moderate anemia were given a higher dose of iron and folic acid tablets containing $60 \mathrm{mg}$ of elemental iron and $1 \mathrm{mg}$ of folic acid and $7.5 \mu \mathrm{g}$ cyanocobalamine, i.e., 2 tablets daily and those in normal range of hemoglobin were given prophylactic iron and folic acid supplementation, i.e., 1 tablet daily. Those with $<7 \mathrm{~g} \%$ of hemoglobin were given packed cell transfusion or parenteral iron preparations. Status of anemia was found out in the second and third trimester.

\section{DISCUSSION}

In the present study, there were 105 (27.6\%) LBW babies out of 380 babies. Among them, 13 (3.4\%) were between $1000 \mathrm{~g}$ and $<1500 \mathrm{~g}$ and $83(21.8 \%)$ were between 2000 and 2499 g. The similar findings were noted in the study conducted by Noor et al. at Indore, Madhya Pradesh [16]. The WHO reported that $36.8 \%$ delivered LBW babies, that is, baby weight $<2500 \mathrm{~g}$. This was very high in comparison with NFHS-3 data where they reported LBW was $23 \%$ in rural areas in India [17]. Other studies from Indian subcontinent also have documented almost similar percentage of LBW, $30.3 \%$ in study by Deshmukh et al. at Wardha, Nagpur [18]. Velankar at Mumbai [19] reported the incidence as high as $45.2 \%$ and by Negi et al. at Dehradun [20] observed the incidence to be around 23.8\%; whereas, other studies done by Trivedi and in Ahmedabad [21] and Kamaladoss et al. in rural Tamil Nadu [22] reported $20.37 \%$ and $24.6 \%$ LBW, respectively. Despite various efforts done to improve maternal and child health in our country, the prevalence of LBW is still on the higher side.

In the present study, out of 380 women, 259 (68.1\%) women were having gestational age $>37$ weeks and delivered NBW babies ( $>2500$ g). 73 (19.2\%) women were having gestational age $>37$ weeks and delivered IUGR but LBW $(<2500 \mathrm{~g})$ babies. $32(8.5 \%)$ were preterm $(<37$ weeks) and delivered LBW $(<2500 \mathrm{~g})$ and $16(4.2 \%)$ women delivered preterm babies ( $<37$ weeks) but had NBW (Table 2). Similar results were seen in a study done by Bisai, in Kolkata, India [23]. The researchers found that among all births, $9.97 \%$ were preterm (<37 weeks) and 90.03\% were term (37-41 weeks) neonates. Similarly, among all LBW babies, $80.16 \%$ were term and $19.84 \%$ were preterm. Other study done by Temu et al. in Northern-eastern Tanzania [24] noted a high prevalence of preterm deliveries, i.e., 14.2\%. Mahande et al. in Northern Tanzania [25] estimated the prevalence of preterm delivery in the study which was higher $19.9 \%$ than that reported in Tanzania of $12 \%$ and 11\%, respectively, by Watson et al. [26] and Kinney et al. at London, UK [27].

In the present study, $33(8.7 \%)$ mothers consumed $<70 \%$ of kcal and the mean birth weight of the babies born to this mothers was lowest, i.e., $2121.4 \pm 340$ and a very high proportion of LBW $(93.9 \%)$ [9]. The higher proportion of LBW babies, i.e., 105 (32.2\%) were delivered by the mothers consuming $<70 \%$ of protein $(\mathrm{p}<0.001)$. There was significant correlation between birth weight and proportion of calorie intake of mothers $(\mathrm{p}<0.001)$ (Table 3$)$. Similar findings were noted by

Table 4: Anthropometric indices and birth weight

\begin{tabular}{|c|c|c|c|}
\hline Anthropometric indices & n (\%) & Mean birth weight in $(g) \pm S D$ in $(g)$ & Number of LBW (\%) \\
\hline \multicolumn{4}{|l|}{ Weight at registration in (kg) } \\
\hline$<4$ & $86(22.6)$ & $2734.0 \pm 482.7$ & $21(24.4)$ \\
\hline $40-45$ & $106(27.9)$ & $2764.5 \pm 487.5$ & $25(23.6)$ \\
\hline $45-50$ & $69(18.2)$ & $2679.9 \pm 490.9$ & $19(27.5)$ \\
\hline $50-55$ & $119(31.3)$ & $2656.8 \pm 484.0$ & $40(33.6)$ \\
\hline \multicolumn{4}{|l|}{ Height of mother in $(\mathrm{cm})$} \\
\hline$\leq 145$ & $22(5.8)$ & $2721.1 \pm 448.4$ & $8(36.4)$ \\
\hline $151-155$ & $116(30.5)$ & $2698.4 \pm 509.4$ & $34(29.3)$ \\
\hline $156-160$ & $104(27.4)$ & $2769.2 \pm 447.7$ & $23(22.1)$ \\
\hline $161-165$ & $37(9.7)$ & $2705.1 \pm 444.2$ & $9(24.3)$ \\
\hline$>165$ & $14(3.7)$ & $2740.4 \pm 448.9$ & $5(35.7)$ \\
\hline \multicolumn{4}{|l|}{ Weight gain in (kg) } \\
\hline$<7.5$ & $37(9.7)$ & $2281.2 \pm 614.7$ & $21(56.8)$ \\
\hline $7.5-<10$ & $46(12.1)$ & $2511.3 \pm 444.8$ & $20(43.5)$ \\
\hline $10-<12.5$ & $100(26.3)$ & $2573.3 \pm 429.4$ & $44(44.0)$ \\
\hline
\end{tabular}

$\mathrm{n}=380$. SD: Standard deviation, LBW: Low birth weight

Table 5: Laboratory parameter, mean birth weight, and proportion of LBW

\begin{tabular}{|c|c|c|c|}
\hline Anemia (hemoglobin level) at registration in (g \%) & n (\%) & Mean birth weight in (g) \pm SD (g) & Number of LBW (\%) \\
\hline Severe anemia & $14(3.7)$ & $2499.3 \pm 478.6$ & $5(35.7)$ \\
\hline Moderate anemia & $110(28.9)$ & $2607.2 \pm 543.9$ & $37(33.6)$ \\
\hline Mild anemia & $164(43.2)$ & $2790.4 \pm 443.1$ & $39(23.8)$ \\
\hline No anemia & $92(24.2)$ & $2715.4 \pm 462.8$ & $24(26.1)$ \\
\hline
\end{tabular}

$\mathrm{n}=380$. SD: Standard deviation, LBW: Low birth weight 
Metgud et al. [28] at Belgaum in rural Karnataka, found a statistically significant relationship between the calorie intake (crude odds ratios [OR] 4.9, 95\% CI 1.7-14.1, $\mathrm{p}=0.003$ ) and birth weight of the newborn as well as protein intake (crude OR $2.1,95 \% \mathrm{CI} 1.2-3.7, \mathrm{p}=0.007$ ). A study done by Raman [29] reported that inadequate calorie intake can result in LBW babies and even supplementation given for anemia correction would not be able to increase the birth weight. Whereas, a study done by Kennedy et al. [30] found that birth weight of baby can be improved with the help of supplementations.

In the present study, 326 (85.8\%) mothers consumed $<70 \%$ of $g$ protein. The mean birth weight of mother was lowest, i.e., $2647.6 \pm 474.7$ and delivered higher proportion of LBW babies, i.e., 31 (93.9). There was significant correlation between birth weight and proportion of protein intake of mothers $(\mathrm{p}<0.001)$ (Table 3$)$. In a study conducted by Raman [29] reported that protein consumption in the range of $30-50 \%$ of total diet reduced chances of LBW babies. The study conducted by Durrani and Rani [31] in Aligarh city, India, have reported that protein intake in all trimesters was also found to be positively correlated with birth weight ( $\mathrm{r}=0.237,0.279$, and 0.348 in the first, second, and third trimesters, respectively). Similarly, Rao et al. [32] at Haryana have reported that the mean protein intake during three dietary assessments was $50.8 \pm 9.27 \mathrm{~g}$. A higher prevalence of LBW babies was observed in pregnant women with mean protein intake of $<40 \mathrm{~g}(p<0.001)$ by AlShosan at Pakistan [33].

Individualized RDA was specific for the concerned pregnant woman and has shown excellent correlation. The proportion of LBW was $<5 \%$ if calories were taken as per individualized RDA, on the other hand, $<70 \%$ of individualized RDA for proteins was sufficient to prevent LBW completely indicating that whatever food is consumed by the mother if calories were taken care of proteins also taken care of. There was no woman in this study who had primary protein deficiency.

If RDA as given by the ICMR taking into consideration, Indian reference woman and the type of work are considered for the mean birth weight, the work groups also showed a significant association, but without individualized RDA values, the correlation could not be worked out which was possible with the individualized RDA values.

In the present study, those mothers consuming less calcium than RDA gave birth to the babies weighing significantly lesser and proportion of LBW being significantly higher than the babies born to mothers consuming calcium equal to or above $1200 \mathrm{mg} /$ day $(\mathrm{p}<0.001)$. There was a significant association and correlation between proportion of calcium intake and birth weight $(\mathrm{p}<0.001)$ (Table 3). The similar findings were noted by Durrani and Rani [31] in Aligarh city, India, has reported that calcium consumption was found to be positively correlated with birth weight in the first $(\mathrm{r}=0.276)$, second $(\mathrm{r}=0.355)$, and third $(r=0.421)$ trimester. Similarly, significant correlations were found between adequate maternal calcium and Vitamin D intake with birth weight. Another researcher Gopalan et al. [14] at Hyderabad also found that the highest mean birth weight was observed among mothers consuming $\geq 1000 \mathrm{mg} / \mathrm{d}$ of calcium.

In the present study, those mothers with less iron intake than RDA gave birth to babies weighing significantly lesser and proportion of LBW babies being significantly higher than the babies born to mothers consuming iron $35 \mathrm{mg}$ or more every day $(\mathrm{p}<0.001)$. There was a significant correlation between birth weight and proportion of iron intake of mothers $(\mathrm{p}<0.001)$.

In the study conducted by Khanal et al. [34] in Nepal noted that intake of iron supplements during pregnancy was found to have a protective effect with respect to LBW. In another study by Rizvi et al. [44] at Karachi noted that iron supplementation was found to be significantly associated a reduction in LBW. In another study by Khoushaabi and Saraswathi in Mysore city, India [35], also showed that the high intake of calcium and iron significantly influenced the birth weight of babies.
Pregnant women with higher intake of minerals gave birth to neonates with normal weight, while pregnant women with lower intake gave birth to LBW neonates noted by Mridula et al. [36].

In the present study, weight of mother at registration and height was not associated with the rate of LBW babies. Similar findings were noted by Gebregzabiherher et al. [37].

In the present study, the mean weight gain from registration to delivery was $11.5 \mathrm{~kg}$ with an SD of $2.6 \mathrm{~kg}$ and minimum weight gain was $4 \mathrm{~kg}$ the maximum gain in weight was $15.1 \mathrm{~kg}$. There was a significant direct correlation between the weight gain of the mother and the birth weight of the baby. As the weight gain increased, the mean birth weight also increased. Similar findings were reported by Sengupta et al. [38] in Ludhiana, Punjab; Mumbare et al. [39] at Nashik, India; Singh et al. [40] at Nepal; Sutan et al. [41] at Kuala Lumpur, Malaysia; and Ghani et al. [42] at West of Algeria. The study conducted by Metgud et al. at Belgaum in rural Karnataka [28] revealed that low weight gain during pregnancy was a risk factor significantly associated with the LBW of the newborn. Moller et al. [43] have shown in African women that total pregnancy weight gain to be of $6 \mathrm{~kg}$. The mean weight gain during pregnancy in India was only about $6 \mathrm{~kg}$ in a study by Anderson [45] in rural India.

In the present study, there was a significant difference between the basic hemoglobin level of the mothers at registration and the birth weight of the baby ( $\mathrm{p}=0.007)$. The mean birth weight increased with increasing hemoglobin values. Similar findings were noted by Kumar et al. [46] at Tumkur, Karnataka, India. That low maternal hemoglobin concentration was associated with LBW babies. The hemoglobin level $(<8 \mathrm{~g} / \mathrm{dl}-\geq 11 \mathrm{~g} /$ dl) during pregnancy was significantly associated with LBW as reported by many studies $[40,47,48]$. In another study by Metgud et al. [28] at Belgaum in rural Karnataka, noted that maximum (80.0\%) number of LBW babies were born to mothers with hemoglobin level, $7 \mathrm{~g} / \mathrm{L}$ (severe anemia) in the third trimester. The leaves of Colocasia esculenta (Alluu) and Alternanthera sessilis $(436.7 \pm 14.9 \mathrm{mg} / 100 \mathrm{~g}$ ) [49] are rich source of calcium and iron [49]; hence it is advised to include this rich source of iron and calcium in the pregnant mother's diet.

Heat treatment improves food safety. Proteins are oxidized during heat treatment. However, heat treatment decreases the nutritional value of food. So it is very important to monitor protein changes caused by heat treatment to ensure benefits and to minimize all negative effects. [50] So it is advised to the pregnant mothers, to avoid heating the protein food again and again because it destroys the nutritive value of protein.

\section{CONCLUSION AND RECOMMENDATIONS}

Thus, intake of calories, proteins, calcium, and iron correlate with the birth weight of the baby and the proportion of LBW. Among anthropometric parameters, weight gain during pregnancy showed correlation. Anemia at first trimester also was identified as an important risk factor.

1. Adequacy of calories and proteins should be ensured during antenatal visits by advising more frequent and sufficient quantities of food available at home.

2. Enrollment of the eligible mothers at Anganwadi centers of ICDS scheme for dietary supplementation should be ensured.

3. Health education of the pregnant woman, the mother, mother-in-law, and husband should be undertaken to bridge the food gap of the women during pregnancy to prevent the LBW.

4. Inadequate weight gain should be identified early and timely dietary interventions undertaken.

5. Anemia prophylaxis during adolescence and supplementation during pregnancy will go a long way for prevention of anemia in pregnancy.

\section{ACKNOWLEDGMENT}

The research work was carried out in the Department of Obstetrics and Gynecology and the researcher are thankful to Dr. R.P. Patange; 
professor and HOD and all the staff of Obstetrics and Gynecology for extending all the cooperation during research work. We also acknowledge the efforts of the participant pregnant women and contribution made by them.

\section{AUTHORS' CONTRIBUTIONS}

Concept, data collection, and writing of article - Mr. Avinash H. Salunkhe - Corresponding author; Guidance and critical review, editing content matter up to satisfactory level and final approval of article. Dr. Asha Pratinidhi; Valuable guidance in using relevant statistical test for analyzing data with significance of test results - Dr. S. V. Kakade; Rewriting and drafting with valuable corrections and guidance - Dr. Jyoti A. Salunkhe; Permitting official and sparing me for completion of this paperwork - Dr. Vaishali. R. Mohite; Formatting, typing, and statistical work- Trupti Bhosale.

\section{CONFLICTS OF INTEREST}

Nil.

\section{REFERENCES}

1. WHO, UNICEF. Low Birth Weight: Country, Regional and Global Estimates. NewYork: WHO, UNICEF; 2004

2. UNSCN (United Nations Sub-Committee on Nutrition). $5^{\text {th }}$ Report on the World Nutrition Situation. Nutrition for Improved Development Outcomes. New York: UNSCN; 2004.

3. Behrman J, Alderman H, Haddinott J. Hunger and malnutrition. Copenhagen Consensus Challenge Paper, Copenhagen Consensus. Copenhagen, Denmark: Environmental Assessment Institute; 2004.

4. Martorell R. The nature of child malnutrition and its long-term implications. Food Nutr Bull 1999;20:288-2.

5. Villar J, Belizan JM. The relative contribution of prematurity and fetal growth retardation to low birth weight in developing and developed societies. Am J Obstet Gynecol 1982;143:793-8.

6. Dinh PH, To TH, Vuong TH, Hojer B, Persson LA. Maternal factors influencing the occurrence of low birth weight in northern Vietnam. Ann Trop Paediatr 1996;16:327-33.

7. Ramakrishnan $\mathrm{U}$, Martorell R, Schroeder DG, Flores, R. Intergenerational effects on linear growth. J Nutr 1999;129:544-9.

8. Raman L, Rao KV, Adinarayana K, Rawal A, Vasumathi N, Parvati CH, et al. Risk care approach to anaemia in pregnancy in an urban slum. Bull World Health Organ 1995;73:75-6.

9. Kulkarni B, Shatrugna V, Balakrishna N. Maternal lean body mass may be the major determinant of birth weight: A study from India. Euro $\mathrm{J}$ Clin Nutr 2006;60:1341-4.

10. Naidu AN, Rao NP. Body mass index. A measure of the nutritional status in Indian populations. Eur J Clin Nutr 1994;48:S131-40.

11. Dharmalingam A, Navaneetham K, Krishnakumar CS. Nutritional status of mothers and low birth weight in India. Matern Child Health J 2010;14:290-8.

12. Thame M, Wilks RJ, McFarlane Anderson N, Bennett FI, Forrester TE. Relationship between maternal nutritional status and infant's weight and body proportions at birth. Eur J Clin Nutr 1997;51:134-8.

13. Nutrient Requirement and Recommended Dietary Allowances for Indians. A Report of the Expert Group of the Indian Council of Medical Research Final Draft. Vol. 500604. Hyderabad: National Institute of Medical Research; 2009. p. 69

14. Gopalan C, Sastri BV, Balasubramanian SC. Nutritive value of Indian foods National Institute of Nutrition. Hyderabad: ICMR; 2011.

15. Park K. Text Book of Preventive and Social Medicine. $23^{\text {rd }}$ ed. Jablapur, India: Ms. Banarsidas Bhanot Publishers; 2015. p. 636

16. Noor N, Kural M, Joshi T, Pandit D, Patil A. A. Study of maternal determinants influencing birth weight of newborn. Arch Med Health Sci $2015 ; 3: 239-3$

17. International Institute for Population Sciences: Macro International. National Family Health Survey NFHS-3 2005-06. Vol. 1. India: IIPS; 2007.

18. Deshmukh JS, Motghare DD, Zodpey SP, Wadhva SK. Low birth weight and associated maternal factors in an urban area. Indian Pediatr 1998;35:33-6.

19. Velankar DH. Maternal factors contributing to low birth weight babies in an urban slum community of greater Mumbai. Bombay Hosp J 2009;51:26-5

20. Negi KS, Kandpal SD, Kukreti M. Epidemiological factors affecting low birth weight. JK Sci J Med Educ Res 2006;8:31-4.

21. Trivedi CR, Mavalankar DV. Epidemiology of low birth weight in Ahmadabad. Ind J Pediatr 1986;53:795-5.

22. Kamaladoss T, Abel R, Sampathkumar V. Epidemiological co-relates of low birth weight in rural Tamil Nadu. Indian J Pediatr 1992;59:299-4.

23. Bisai S. Maternal height as an independent risk factor for neonatal size among adolescent Bengalees in Kolkata. India Ethiop J Health Sci 2010;20:153-8.

24. Temu TB, Masenga G, Obure J, Mosha D, Mahande MJ. Maternal and obstetric risk factors associated with preterm delivery at a referral hospital in northern-eastern Tanzania. Asian Pac J Reprod2016;5:365-70

25. Mahande MJ, Daltveit AK, Obure J, Mmbaga BT, Masenga G, Manongi $\mathrm{R}$, et al. Recurrence of preterm birth and perinatal mortality in northern Tanzania: Registry-based cohort study. Trop Med Int Health 2013;18:962 7 .

26. Watson JD, Weiss HA, Changalucha JM, Todd J, Gumodoka B, Bulmer J, et al. Adverse birth outcomes in United Republic of Tanzania-impact and prevention of maternal risk factors. Bull World Health Organ 2007;85:9-8.

27. Kinney MV, Lawn JE, Howson CP, Belizan J. Million preterm births annually: What has changed this year? Reprod Health 2012;9:28.

28. Metgud CS, Naik VA, Mallapur MD. Factors affecting birth weight of a newborn-A community based study in rural Karnataka, India; 2012. Available from: http://www.Journal plos.org pone 0040040 . [Last accessed on 2012 Jul 05].

29. Raman L. Influence of maternal nutritional factors affecting birthweight. Am J Clin Nutr 1981;34:775-3.

30. Kennedy ET, Gershoff S, Reed R, Austin JE. Evaluation of the effect of WIC supplemental feeding on birth-weight. J Am Dietic Assoc 1984;80:220-7.

31. Durrani AM, Rani A. Effect of maternal dietary intake on the weight of the newborn in Aligarh city, India Niger Med J 2011;52:177-1.

32. Rao BT, Aggrawal AK, Kumar R. Dietary intake in third trimester of pregnancy and prevalence of LBW. A community-based study in a rural area of Haryana. Indian J Community Med 2007;32: 272-6.

33. Al-Shosan A. Diet history and birth weight relationship. Pak J Med Sci 2007:23:176-1.

34. Khanal V,Zhao Y, Sauer K. Role of antenatal care and iron supplementation during pregnancy in preventing low birth weight in Nepal: Comparison of national surveys 2006 and 2011. Arch Public Health 2014;72:4

35. Khoushaabi F, Saraswathi G. Association between maternal nutrition status and birth weight of neonates in selected hospitals in Mysore city, India. Pak J Nutr 2010;9:1124-30.

36. Mridula D, Mishra CP, Chakraverty A. Effect of mother's dietary intake on birth weight of newborn. Indian J Nutr Diet 2002;39:327-2.

37. Gebregzabiherher Y, Haftu A, Weldemariam S, Gebrehiwet H. The prevalence and risk factors for low birth weight among term newborns in Adwa General Hospital. Northern Ethiop Obstet Gynecol Int 2017;2017: Article ID: 2149156, 7.

38. Sengupta P, Sharma N, Benjamin AI. Risk factors for low birth weight. A case-control study in Ludhiana, Punjab. Indian J Matern Child Health 2009;11:1-4.

39. Mumbare SS, Maindarkar G, Darade R, Yenge S, Tolani MK, Patole K. Maternal risk factors associated with term low birth weight neonates: A matched-pair case-control study. Indian Pediatr 2012;49:25-8

40. Singh SD, Shrestha S, Marahatta SB. Incidence and risk factors of low birth weight babies born in Dhulikhel hospital. J Inst Med 2010;32:39 2.

41. Sutan R, Mohtar M, Mahat AN, Tamil AM. Determinant of low birth weight infants -A matched case control study. Open J Prev Med 2014:4:91 9

42. Ghani AE, Mai H, Demmouche A. Epidemiology of low birth weight in the town of Sidi Bel Abbes (West of Algeria)- A case-control study. J Nutr Food Sci 2014:4:278

43. Moller B, Gebre-Medhin M, Lindmark G. Maternal weight, weight gain and term in the rural Tanzanian village of Hula. Br J Obstet Gynaecol 1989;96:158-6.

44. Rizvi SA, Hatcher J, Jehan I, Qureshi R. Maternal risk factors associated with low birth weight in Karachi: A case control study Estern Mediterranen Health journal 2007; 13(6): 1343-52.

44. Anderson MA. Relationship between maternal nutrition and child growth in rural India [Doctoral Thesis]. Medford, Mass, USA: Tufts University; 1989.

45. Kumar V. Maternal and neonatal factors among low birth weight babies- A tertiary care hospital based study. Curr Pediatr Res 2014;18:73-5.Available from: http://www.currentpediatrics.com.

46. Jayant DD, Phalke DB, Bangal VB, Peeyuusha D, Sushen B. Maternal risk factors for low birth weight neonates: A hospital based case control 
study in rural area of western Maharashtra, India. Natl J Community Med 2011;2:394-8

47. Rahman MS, Howlader T, Masud MS, Rahman ML. Association of low-birth weight with malnutrition in children under five years in Bangladesh: Do mother's education, socio-economic status, and birth interval matter? PLoS ONE 2016;11:e0157814.
48. Kumar GM, Chikkapaih L, Nagayya S. Nutritional analysis of edible wild plants used by Hakki Pikki tribes of Hassan district, Karnataka, India. Int J Pharm Pharm Sci 2016;8:390-3.

49. Zrekah G, et al. Determination of protein and fat oxidation levels in imported infant formula available in Syria. Int J Pharm Pharm Sci 2016;8:169-72. 